\title{
Proposal for an index of water quality for micro-watersheds under silviculture management
}

\author{
Proposta de um índice de qualidade de águas para microbacias hidrográficas sob \\ manejo silvicultural
}

\author{
Benvindo Sirtoli Gardiman JuniorI, Giovanni de Oliveira Garcia' ${ }^{\mathrm{II}}$, \\ Roberto Avelino Cecílio ${ }^{\mathrm{III}}$, Rodolfo Araújo Loos ${ }^{\mathrm{IV}}$
}

\begin{abstract}
This work aimed to develop a Water Quality Index (WQI) for the forestry sector. Therefore, to achieve this purpose, the physical and chemical characteristics of the water were monitored: $\mathrm{Ca}, \mathrm{Cu}, \mathrm{Fe}, \mathrm{K}, \mathrm{Mg}$, Na, P, S, Zn, IC, OC, Chlor, Nitr, Sulf, Phosp, Ammo, Glyph, Alka, EC, Color, COD, CH, MH, DO, SS, DS, Sulfl, Temp, Turb and $\mathrm{pH}$ in four micro-watersheds (MW) under activities of forest management in the city of Aracruz, Espírito Santo, Southeast of Brazil, from January to June, 2012. The multivariate statistical analyses, the Principal Component Analysis (PCA) and the Factor Analysis (FA) indicated that the most significant variables in the variation of water quality to compose a WQI were: EC, Color, Chlor, Nitr, Mg, Alka, Na, IC, OC, Fe, pH and SS, responsible for a total variance of $61.77 \%$ of the data after the rotation of the factors using the normalized Varimax method. Variables related to the dissolved salts in water assumed higher weights due to the proximity with the sea. The proposed WQI proved itself to be efficient when evaluating the water quality of the monitored micro-watersheds, instead examining the variables independently.
\end{abstract}

Keywords: Multivariate statistics; Principal component analysis; Water quality variables.

\section{Resumo}

Neste trabalho objetivou-se elaborar um Índice de Qualidade das Águas (IQA) para o setor florestal. Para isso, monitoraram-se as características físicas e químicas da água: $\mathrm{Ca}, \mathrm{Cu}, \mathrm{Fe}, \mathrm{K}, \mathrm{Mg}, \mathrm{Na}, \mathrm{P}, \mathrm{S}, \mathrm{Zn}, \mathrm{CI}, \mathrm{CO}$, Clor, Nitr, Sulf, Fosf, Amô, Glif, Alca, CE, Cor, DQO, DC, DC, OD, SS, SD, Sulfl, Temp, Turb e pH, em quatro microbacias hidrográficas (MBs) sob atividades do manejo florestal no município de Aracruz - ES, de janeiro a junho de 2012. As técnicas de estatística multivariadas, Análise de Componentes Principais (ACP) e Análise Fatorial (AF), indicaram que as variáveis mais representativas da variação da qualidade das águas para compor um IQA são: $\mathrm{CE}$, Cor, Clor, Nitr, Mg, Alca, $\mathrm{Na}, \mathrm{Na}, \mathrm{CI}, \mathrm{CO}, \mathrm{Fe}, \mathrm{pH}$ e SS, responsáveis por uma variância total de $61,77 \%$ dos dados após a rotação dos fatores pelo método Varimax normatizado. As variáveis relacionadas aos sais dissolvidos na água assumiram maiores pesos, em consequência da proximidade do mar. O IQA proposto demonstrou ser eficiente para avaliar a qualidade das águas das MBs monitoradas, ao invés de examinar as variáveis independentemente.

Palavras-chave: Estatística multivariada; Análise de componentes principais; Variáveis de qualidade da água.

\footnotetext{
Engenheiro Ambiental, Dr., Professor do Instituto Federal de Educação, Ciência e Tecnologia do Espírito Santo, Av. Sete de Novembro, 40, CEP 29350-000, Ibatiba (ES), Brasil. benvindo.gardiman@ifes.edu.br (ORCID: 0000-0001-5197-4970)

Engenheiro Agrônomo, Dr., Professor Associado do Departamento de Engenharia Rural, Universidade Federal do Espírito Santo, Alto Universitário, s/n, CEP 29500-000, Alegre (ES), Brasil. giovanni.garcia@ufes.br (ORCID: 0000-0003-1326-9909)

III Engenheiro Agrícola, Dr., Professor Associado do Departamento de Engenharia Florestal e da Madeira, Universidade Federal do Espírito Santo, Av. Gov. Lindemberg, 316, CEP 29550-000, Jerônimo Monteiro (ES), Brasil. roberto.cecilio@ufes.br (ORCID: 0000-0003-2894-2481)

IV Engenheiro Agrônomo, Dr., Pesquisador da Fibria Celulose S.A., Rod. Aracruz-Barra do Riacho, s/n, Km 25, CEP 29197-900, Aracruz (ES), Brasil. raloos@fibria.com.br (ORCID: 0000-0001-7280-3396)
} 


\section{Introduction}

Currently, a major concern of humanity relates to the environment, particularly regarding water quality around the world (GRÜTZMACHER et al., 2008). Such as, in agricultural activities, transport of nutrients, solid material and even agrochemicals, which are thrown into the river, have disturbed the water quality (GUIMARÃES et al., 2010). Thus, the identification of water quality factors, especially in the agro-forestry sector has been the focus of attention in many countries (MENEZES et al., 2009; GUIMARÃES et al., 2010).

Furthermore, due to the difficulty of understanding and harmonizing information relating to the condition of a water sample, several quality indices have been developed in various parts of the world, especially in sectors in which there are still no defined indexes (CARVALHO et al., 2011).

Usually, these Water Quality Indexes (WQI's) are based on few variables (GERGEL et al., 2002), those definitions should reflect upon potential or actual changes, natural or anthropogenic, which the water suffered (TOLEDO; NICOLELLA, 2002).

A WQI can be designed to a specific situation, inserted in the context of a watershed, that is, the elaboration of a WQI can be simplified by taking into account only the critical environmental variables that affect a particular water body at a given time (SILVA; JARDIM, 2006). This occurs because each system has its own characteristics, which hinders the establishment of a single variable as a standard indicator for any water system (TOLEDO; NICOLELLA, 2002).

Several techniques have been used to the elaboration of a water quality index, and several are based in the WQI developed by the National Sanitation Foundation (NSF) of the United States, and used in other countries like Brazil and England (VON SPERLING, 2005). Usually, it is calculated by the weighted product operator of the qualities of the water corresponding to the selected parameters (CARVALHO et al., 2011). Thus, for each variable a weight according to its relative importance when calculating the WQI is assigned, and the average curves of assessment of the water quality are drawn in function of its concentration (VON SPERLING, 2005).

Several researchers have studied the structure of WQI's through the use of multivariate statistics to choose the most representative variables, standing out in the elaboration and creation of these indexes based on the Factor Analysis (FA) and the Principal Component Analysis (PCA) (TOLEDO; NICOLELLA, 2002; ALMEIDA; SCHWARZBOLD, 2003; ANDRADE et al., 2005; GIRÃO et al., 2007; ANDRADE et al., 2007a; 2007b; MOURA et al., 2010), and also through comparisons (CARVALHO et al., 2000; BONNET et al., 2008; BARROS et al., 2011; CARVALHO et al., 2011; NUNES et al., 2011).

It is noteworthy that a unique and standard index of water quality for any water system does not exist (TOLEDO; NICOLELLA, 2002), there are different indexes for each specific use, such as for the protection of the aquatic life, first contact recreation and human consumption, for areas of brackish water and estuaries, and for fishing (TOLEDO; NICOLELLA, 2002).

In this context, this study aimed to develop a WQI for micro-watersheds under activities of silviculture management in the city of Aracruz, state of Espírito Santo, Southeast of Brazil.

\section{Material and methods}

The study is limited to four headwater micro-watersheds (MW's) under commercial eucalyptus plantations belonging, located in the city of Aracruz, Espírito Santo, Brazil. The collection points are located at UTM coordinates in the following locations: MW 1 at 379692 E and 7817606 N, MW 2 at $384537 \mathrm{E}$ and $7798137 \mathrm{~N}, \mathrm{MW} 3$ at $377409 \mathrm{E}$ and $7820538 \mathrm{~N}$ e MW 4 at $370117 \mathrm{E}$ and $7808778 \mathrm{~N}$, at an altitude ranging between 10 and 50 meters above sea level, as illustrated in Figure 1. 
Figure 1 - Location of the study area in Aracruz, Espírito Santo, Southeast of Brazil.

Figura 1 - Localização da área de estudo em Aracruz, Espírito Santo, sudeste do Brasil.

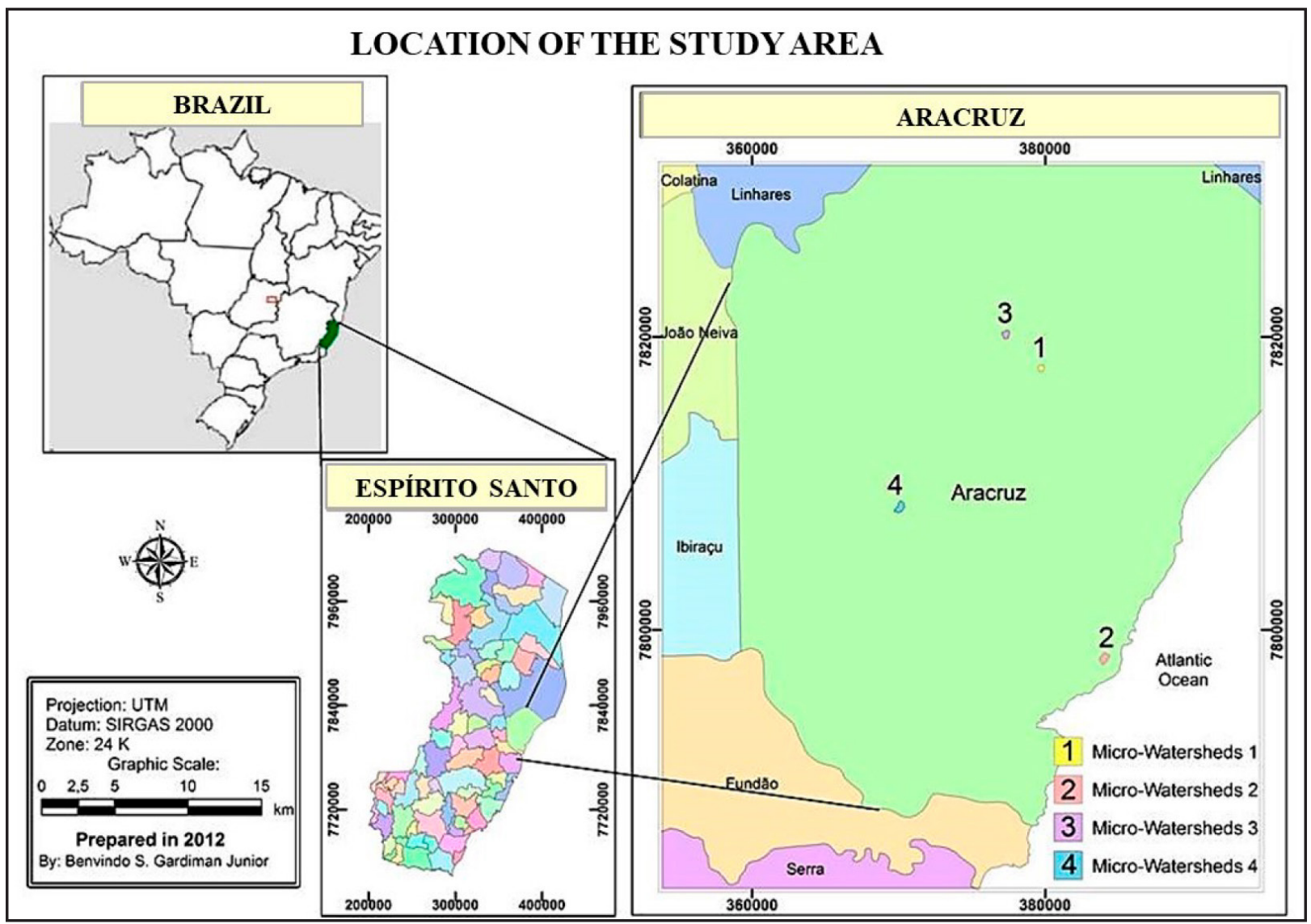

Source: Gardiman Junior et al. (2019)

The region's weather according to the classification of Köppen is Aw (tropical humid, with a rainy summer and a dry winter). The average rainfall is around $1200 \mathrm{~mm}$ per year, mainly on spring and summer (October to March), when $65-80 \%$ of it occurs (ALVARES, 2013).

In order to identify changes in water quality variables, exclusively to silvicultural activities, in an index, some criteria for the selection and delimitation of the micro-watersheds were adopted:

They should have a first order stream of perennial water in its interior;

They should have ongoing or planned operational activities of silvicultural management during the period of study;

Preferably, possess in their planning a scheme for the renovation of plantations so that a greater number of activities could be contemplated;

Have no influence of any other use or soil coverage unless eucalyptus and their essential permanent preservation areas;

To have permanent preservation areas (riparian zones) preserved and occupied by native vegetation;

Present uniformity in the flow of water courses; and

Be spatially well distributed within the company areas of Eucalyptus grandis plantations.

To avoid the influence of the MW's soil on the variables of water quality, the chemical characterization of the soils was at depths of $0-40 \mathrm{~cm}$ for the following chemical parameters: 
phosphorus, potassium, calcium, magnesium, potential acidity $(\mathrm{H}+\mathrm{Al})$, organic matter $(\mathrm{OM})$ and $\mathrm{pH}$. In possession of those values, the sum of bases $(\mathrm{SB})$, base saturation $(\mathrm{V})$ and cation exchange capacity at $\mathrm{pH} 7(\mathrm{~T})$ were calculated, as can be seen in Table 1 .

Table 1 - Chemical characterization ${ }^{1}$ of the soils* of the monitored micro-watersheds (MW).

Tabela 1- Caracterização química ${ }^{\mathbf{1}}$ dos $\operatorname{solos}^{*}$ das microbacias hidrográficas (MB) monitoradas.

\begin{tabular}{|c|c|c|c|c|c|c|c|c|c|c|}
\hline MW & $\begin{array}{l}\mathbf{P} \\
--\mathbf{m} \\
\end{array}$ & $\begin{array}{r}K \\
\mathrm{dm}^{-3--} \\
\end{array}$ & $\mathrm{Ca}$ & Mg & $\begin{array}{c}\mathrm{H}+\mathrm{Al} \\
\mathrm{mol}_{\mathrm{c}} \mathbf{d m}^{-3}\end{array}$ & $\begin{array}{l}\text { Sum of } \\
\text { Bases }\end{array}$ & $T$ & $\begin{array}{l}\mathrm{V} \\
(\%)\end{array}$ & $\begin{array}{c}\mathrm{OM} \\
\text { dag } \mathrm{kg}^{-1} \\
\end{array}$ & pH \\
\hline 1 & $3.0 \pm 1.4$ & $13.7 \pm 2.7$ & $0.40 \pm 0.16$ & $0.13 \pm 0.05$ & $4.72 \pm 0.07$ & $2.76 \pm 0.07$ & $7.48 \pm 0.5$ & $36.6 \pm 1.5$ & $1.70 \pm 0.3$ & $4.0 \pm 0.07$ \\
\hline 2 & $15.0 \pm 10$ & $16.6 \pm 4.1$ & $0.61 \pm 0.05$ & $0.18 \pm 0.03$ & $3.17 \pm 0.24$ & $4.11 \pm 0.3$ & $7.28 \pm 0.6$ & $56.4 \pm 2.4$ & $1.65 \pm 0.2$ & $4.1 \pm 0.18$ \\
\hline 3 & $7.1 \pm 4.4$ & 22.86 .4 & $1.03 \pm 0.24$ & $0.21 \pm 0.03$ & $2.94 \pm 0.7$ & $6.50 \pm 0.09$ & $9.44 \pm 0.8$ & $68.8 \pm 3.5$ & $2.37 \pm 0.4$ & $4.1 \pm 0.28$ \\
\hline 4 & $7.7 \pm 2.4$ & $12.7 \pm 4.1$ & $1.03 \pm 0.6$ & $0.14 \pm 0.03$ & $3.92 \pm 0.02$ & $5.89 \pm 0.2$ & $9.81 \pm 0.5$ & $60.0 \pm 2.5$ & $2.20 \pm 0.6$ & $4.1 \pm 0.25$ \\
\hline
\end{tabular}

${ }^{1}$ Average and standard deviation of the values of tests performed at depths. ${ }^{*}$ Legend: $\mathrm{P}=$ Phosphorus, $\mathrm{K}=$ Potassium, $\mathrm{Ca}=$ Calcium, $\mathrm{Ma}=$ Magnesium, $\mathrm{H}+\mathrm{Al}=$ Potential Acidity, $\mathrm{T}=$ Cation exchange capacity at $\mathrm{pH} 7, \mathrm{OM}=$ Organic Matter, $\mathrm{V}=$ Saturation of bases and $\mathrm{pH}=$ Hydrogenation potential

Water samples were collected, in plastic or glass bottles, a sample in triplicate for each activity, for about five months (Jan/2012 to Jun/2012) in the central point of the watercourses. The collect was performed after the conducting of any silvicultural activity and a rain event, the latter confirmed by means of stations interlinked to the company network of weather monitoring. Before monitoring, samples of water were collected at the same point before any silvicultural activity and rainfall event, since, theoretically, there was no change in the reference environment. The monitored activities can be found in Table 2 .

The water samples were preserved according to procedures described in the technical norm ABNT NBR 9898 (1987). The detection methods employed followed the precepts of the American Public Health Association (2005) for Calcium (Ca), Copper (Cu), Iron (Fe), Potassium $(\mathrm{K})$, Magnesium (Mg), Sodium (Na), Phosphorus (P), Exofre (S), Zinc (Zn), Inorganic Carbon (IC), Organic Carbon (OC), Chloride (Chlor), Nitrate (Nitr), Sulphate (Sulf), Phosphate (Phosp), Ammonia (Ammo), Glyphosate (Glyph), Alkalinity (Alka), Chemical Oxygen Demand (COD), Calcium Hardness (CH), Magnesium Hardness (MH), Suspended Solids (SS), Dissolved Solids (DS), Sulfluramide (Sulfl). While Electrical Conductivity (EC), Color, Dissolved Oxygen (DO), Temperature (Temp), Turbidity (Turb) and $\mathrm{pH}$ by properly calibrated equipment.

The raw water quality variables $(q i)$ were subjected to standardization or normalization of the data, that is, the average was zero $(\mu=0)$ and the variance was one $(\sigma=1)$, as also assumed by many authors (ANDRADE et al., 2003).

In order to correlate the variables that assess the quality of surface waters, multivariate statistical techniques were used: Factor Analysis/Principal Component Analysis (FA/PCA). The number of factors was chosen by factorial loads above 0.7 and cumulative variance above $60 \%$ (ANDRADE et al., 2005).

After evaluating the results of the variables using FA/PCA, a Water Quality Index (WQI) was elaborated using the representative variables for the selected factors. The rotation of the matrix of factorial loads was performed by the standardized Varimax method, which approximates the factorial matrix loads by 1 or -1 , facilitating the visualization (ANDRADE et al., 2003; 2007a; 2007b). 
Table 2 - Silvicultural activities monitored in the four micro-watersheds (MW's) in Aracruz, Espírito Santo state, Brazil.

Tabela 2 - Atividades silviculturais monitoradas nas quatro microbacias hidrográficas (MBs) em Aracruz, Espírito Santo, Brasil.

\begin{tabular}{|c|c|c|}
\hline MW & Activ $^{2}$ & Description of activities $^{3}$ \\
\hline 1 & 1 & Witness (without any silvicultural intervention) \\
\hline 1 & 2 & Opening of roads, harvesting and transportation \\
\hline 1 & 3 & $\begin{array}{l}\text { Cleaning of control strains and first control of leafcutter ants with the distribution of } \\
\text { sulfluramide-based granular bait }(0.03 \% \text { of active principle) }\end{array}$ \\
\hline 1 & 4 & First control of leafcutter ants \\
\hline 2 & 1 & Witness (without any silvicultural intervention) \\
\hline 2 & 5 & Mowing \\
\hline 2 & 4 & First control of leafcutter ants \\
\hline 2 & 6 & First control of leafcutter ants and opening of roads \\
\hline 2 & 7 & Harvest \\
\hline 3 & 1 & Witness (without any silvicultural intervention) \\
\hline 3 & 8 & $\begin{array}{l}\text { First control of leafcutter ants, chemical weed control before planting, chemical elimination of } \\
\text { strain }\end{array}$ \\
\hline 3 & 9 & $\begin{array}{l}\text { Chemical elimination of strain, chemical weed control before planting, subsoiling with } \\
\text { fertilization, cleaning of the planting line }\end{array}$ \\
\hline 3 & 10 & Subsoiling with fertilization and planting \\
\hline 3 & 11 & Planting \\
\hline 3 & 12 & Second control of leafcutter ants \\
\hline 3 & 13 & Chemical weed control after planting \\
\hline 3 & 15 & Third month fertilization \\
\hline 4 & 1 & Witness (without any silvicultural intervention) \\
\hline 4 & 7 & Harvest \\
\hline 4 & 14 & $\begin{array}{l}\text { First control of leafcutter ants, chemical weed control before planting, chemical elimination of } \\
\text { strain, cleaning of the planting line, subsoiling with fertilization and planting }\end{array}$ \\
\hline 4 & 5 & Mowing \\
\hline
\end{tabular}

The WQI formulated by this method was calculated by the weighed sum of the value of individual quality of each representative variable in the MW's (qi) multiplied by the respective weights of these variables in the assessment of the total variability of water quality (wi) according to equation 1, also used by several authors for the preparation of these indexes(HAASE; POSSOLLI, 1993; TOLEDO; NICOLELLA, 2002; ANDRADE et al., 2005; LOPES et al., 2009).

$$
W Q I=\sum_{1}^{n} q_{i} \cdot w_{i}
$$


In which: WQI is the Water Quality Index, a number between -3 and 3, using this method; $q i$ is the quality of the $i^{\text {th }}$ standard variable; wi is the corresponding weight of the $i^{\text {th }}$ variable, a number between -1 and 1 , attributed according to its importance for the explaining of the variability of water quality obtained by FA and is the number of variables considered by the representative FA/PCA of the study.

Following the precepts presented by Toledo and Nicolella (2002) and Haase and Possolli (1993) when using the FA/PCA to propose a WQI, the values of qi used in this expression correspond to the standard variables, since, in the literature, maximum limits for some of the elected representative variables to compose the factors were not found. The standard variables $q i$ is described according to equation 2 :

$$
\mathrm{q}_{\mathrm{i}}=\frac{\mathrm{X}_{\mathrm{j}} \overline{\mathrm{X}_{\mathrm{i}}}}{\mathrm{S}_{\mathrm{i}}}
$$

In which: $q_{\mathrm{i}}$ is the $i^{\text {th }}$ observation of the $j^{\text {th }}$ standard variable; $\mathrm{X}_{\mathrm{ij}}$ is the $i^{\text {th }}$ value observed of the $j^{\text {th }}$ variable; $\overline{\mathrm{X}}_{i}$ is the average of the $i^{\text {th }}$ and $j^{\text {th }}$ variables; $S_{i}$ is the standard deviation of the variable $X_{i j}$; $i$ is the average of the sample $X_{i j}$; $i$ is the number of variables; and $j$ is the number of collection sites.

To assign the weights (wi) to each quality of water variable used in the WQI the factors extracted by the FA/PCA were taken as the base. The weight value (wi) of each variable was weighted in terms of the characteristic root (eigenvalue) of each factor associated with the explicability of each variable in relation to the principal components extracted. The expression used in the calculation of wi will follow equation 3 and it can be found in some studies in this area (ANDRADE et al., 2005; LOPES et al., 2009).

$$
\mathrm{w}_{\mathrm{i}}=\frac{\left(\mathrm{F}_{1} \cdot \mathrm{P}_{\mathrm{i}}\right)+\left(\mathrm{F}_{2} \cdot \mathrm{P}_{\mathrm{i}}\right)+\left(\mathrm{F}_{\mathrm{k}} \cdot \mathrm{P}_{\mathrm{i}}\right)}{\left(\mathrm{F}_{1} \cdot \sum_{1}^{\mathrm{n}} \mathrm{P}_{\mathrm{i}}\right)+\left(\mathrm{F}_{2} \cdot \sum_{1}^{\mathrm{n}} \mathrm{P}_{\mathrm{i}}\right)+\left(\mathrm{F}_{\mathrm{k}} \cdot \sum_{1}{ }_{1}^{\mathrm{n}} \mathrm{P}_{\mathrm{i}}\right)}
$$

In which: $\mathrm{F}_{1}$ and $\mathrm{F}_{\mathrm{k}}$ are the eigenvalues of the main components; $\mathrm{P}_{\mathrm{i}}$ is the contribution of the variables by the main component; and " $n$ " is the number of variables involved in PCA.

The WQI calculated by this procedure has an average of zero and unitary variance, being between -3 and 3 , the negative values meaning the best water quality (TOLEDO; NICOLELLA, 2002; HAASE; POSSOLLI, 1993). Thus, to facilitate the visualization of the variation of water quality in the studied MW's, the WQI was divided in classes proportional to those proposed by Companhia Ambiental do Estado de São Paulo (2011), as shown in Table 3.

\section{Table 3 - Classification of water quality based on the numeric value of the proposed Water Quality Index (WQI).}

Tabela 3 - Classificação da qualidade da água com base no valor numérico do Índice de Qualidade de Águas (IQA) proposta.

\begin{tabular}{lc}
\hline Numeric value of the WQI & Classification of the water quality \\
\hline-3.0 a -1.9 & Great \\
$-\mathbf{1 . 8}$ a $-\mathbf{0 . 1 3}$ & Good \\
$\mathbf{- 0 . 1 2}$ a 0.79 & Acceptable \\
$\mathbf{0 . 7 8}$ a 1.9 & Bad \\
$\mathbf{1 . 8}$ a 3.0 & Terrible \\
\hline
\end{tabular}




\section{Results and discussion}

Although 30 variables were analyzed, the model presented by the FA/PCA exposed that only 12 of these variables presented a correlation above 0.7 or below -0.7 with at least one of the first four components, responsible for the total variation of $61.77 \%$ of the data.

Table 4 displays the values of the standard variables ( $q$ i) corresponding to each collection of each $\mathrm{MW}$ in chronological order in relation to the monitoring.

\section{Table 4 - Standard water quality variables $(q i)$ used in the calculation of the Water Quality Index (WQI) of each micro-watershed (MW) followed by the dates of collection and monitored activities (Activ) in the city of Aracruz, Espírito Santo state, Brazil.}

Tabela 4 - Variáveis de qualidade de água padronizadas (qi) utilizadas no cálculo do Índice de Qualidade de Águas (IQA) de cada microbacia hidrográfica (MB) seguida das datas de coleta e atividades monitoradas (Ativ) no município de Aracruz, Espírito Santo, Brasil.

\begin{tabular}{|c|c|c|c|c|c|c|c|c|c|c|c|c|c|c|}
\hline \multirow{2}{*}{ MW } & \multirow{2}{*}{ Activ } & \multirow{2}{*}{ Date } & \multicolumn{12}{|c|}{ Variables $^{4}$} \\
\hline & & & EC & Color & Chlor & Nitr & Mg & Alka & $\mathrm{Na}$ & IC & OC & $\mathrm{Fe}$ & pH & SS \\
\hline \multirow{4}{*}{1} & 1 & $25 / 01$ & -0.58 & -0.53 & -0.59 & 1.3 & -0.3 & -0.57 & -0.26 & 0.16 & -0.8 & -0.67 & -1.16 & -0.61 \\
\hline & 2 & $17 / 02$ & -0.27 & -0.7 & -0.32 & 1.53 & 0.09 & -0.47 & -0.51 & -0.84 & 0.6 & -0.66 & -0.41 & -0.72 \\
\hline & 3 & $07 / 03$ & -0.69 & -0.62 & 0.03 & 1.4 & -0.2 & -0.55 & -0.21 & -0.49 & 1.26 & -0.34 & -0.41 & -0.34 \\
\hline & 4 & $19 / 03$ & -0.65 & -0.61 & -0.44 & 1.63 & -0.24 & -0.33 & -0.27 & 0.19 & -0.84 & -0.69 & -0.28 & -0.5 \\
\hline \multirow{5}{*}{2} & 1 & $04 / 01$ & 1.12 & 0.5 & 0.09 & 1.03 & 1.59 & -0.42 & 0.68 & -0.27 & -0.01 & -0.48 & -1.63 & 0.33 \\
\hline & 5 & $17 / 02$ & 1.96 & 2.21 & 2.15 & -1.24 & 1.67 & -0.2 & 1.5 & -0.85 & 1.84 & -0.36 & -0.72 & -0.12 \\
\hline & 4 & $07 / 03$ & 1 & 2.07 & 1.75 & -1.24 & 1.13 & -0.45 & 1.37 & -0.78 & 2.08 & 0.03 & -0.77 & 0.03 \\
\hline & 6 & $20 / 03$ & 1.12 & 1.81 & 0.41 & -0.99 & 1.52 & 0.18 & 0.81 & -0.02 & 0.27 & -0.11 & 0.06 & 0.33 \\
\hline & 7 & 09/04 & 2.31 & 1.3 & 1.81 & -1.15 & 1.93 & 3.58 & 0.79 & 3.35 & 0.05 & 0.49 & 0.38 & 0.56 \\
\hline \multirow{7}{*}{3} & 8 & $04 / 01$ & -0.42 & -0.66 & -0.49 & 0.94 & -0.78 & -0.28 & -0.73 & -0.42 & -0.68 & -0.22 & 0.71 & -0.42 \\
\hline & 9 & $06 / 01$ & -0.38 & -0.36 & -0.49 & 0.2 & -0.62 & 0.08 & -0.46 & -0.42 & -0.74 & -0.09 & 1.05 & -0.65 \\
\hline & 10 & $13 / 01$ & -0.46 & -0.55 & -0.63 & 0.1 & -0.8 & -0.26 & -0.71 & 0.04 & -0.65 & -0.16 & 1.57 & -0.5 \\
\hline & 11 & $17 / 02$ & 0 & -0.77 & -0.01 & -0.09 & -0.42 & -0.08 & -0.14 & -0.86 & 0.46 & -0.65 & 0.19 & -0.57 \\
\hline & 12 & $07 / 03$ & -0.34 & -0.47 & 0.22 & -0.28 & -0.59 & -0.08 & 0.33 & -0.95 & 1.67 & -0.58 & 0.56 & -0.57 \\
\hline & 13 & $19 / 03$ & -0.34 & -0.63 & -0.23 & 0.03 & -0.72 & -0.16 & 0.04 & -0.31 & -0.75 & -0.71 & 0.56 & -0.57 \\
\hline & 15 & $15 / 05$ & 0.12 & -0.6 & 0.86 & -0.12 & -0.23 & -0.01 & 0.98 & 0.64 & -0.86 & 0.12 & -0.59 & -0.5 \\
\hline \multirow{5}{*}{4} & 1 & $05 / 06$ & -0.19 & -0.42 & -0.25 & -0.33 & -0.54 & -0.43 & 1.07 & -0.02 & -0.83 & -0.38 & 0.95 & -0.19 \\
\hline & 7 & $04 / 01$ & -1.69 & -0.44 & -1.81 & -0.51 & -1.68 & -1.21 & -2.82 & -0.44 & -0.54 & 0.1 & -2.21 & 0.18 \\
\hline & 14 & $09 / 05$ & -0.69 & -0.02 & -0.93 & -1.24 & -0.38 & 1.72 & -1.04 & 1.33 & -0.73 & 1.97 & 0.77 & 1.09 \\
\hline & 1 & $05 / 06$ & -0.92 & -0.53 & -1.13 & -0.99 & -0.41 & -0.05 & -0.42 & 0.95 & -0.8 & 3.39 & 1.37 & 3.73 \\
\hline & 5 & $13 / 06$ & -1.23 & -0.33 & -1.44 & -0.91 & -0.81 & 0.02 & -1.65 & 0.8 & -0.86 & 0.45 & -0.28 & 1.09 \\
\hline
\end{tabular}

${ }^{4} \mathrm{EC}=$ Electrical Conductivity, Color $=$ Color, Chlor $=$ Chloride, Nitr $=$ Nitrate, $\mathrm{Mg}=$ Magnesium, Alka $=$ Alkalinity, $\mathrm{Na}=$ Sodium, $\mathrm{IC}=$ Inorganic Carbon, $\mathrm{OC}=$ Organic Carbon, Fe = Iron, SS = Suspended solids

Using the third equation and based on the factor loading matrix (eigenvalues), the (wi) values for each of the variables in Table 4 were calculated. The sum of all the weights (wi) for each variable is equal to one, as shown in Table 5 . 
Table 5 - Factor loading matrix of the variables rotated by the varimax algorithm in the four main components selected and the wi weights of the variables.

Tabela 5 - Matriz de cargas fatoriais das variáveis rotacionadas pelo algoritmo varimax nos quatro componentes principais selecionados e os pesos wi das variáveis.

\begin{tabular}{lccccc}
\hline & \multicolumn{5}{c}{ Extracted components $^{6}$} \\
\hline Cariables & C1 & C2 & C3 & C4 & Weights (wi) \\
\hline Chlor & 0.935 & -0.126 & 0.118 & 0.174 & 0.1533 \\
Color & 0.861 & 0.270 & -0.152 & 0.089 & 0.1547 \\
EC & 0.845 & -0.039 & -0.031 & 0.351 & 0.1548 \\
Mg & 0.767 & 0.002 & -0.144 & 0.306 & 0.1367 \\
OC & 0.740 & -0.080 & -0.073 & -0.351 & 0.0722 \\
Na & 0.733 & -0.121 & 0.341 & 0.060 & 0.1241 \\
Fe & -0.254 & 0.858 & 0.039 & 0.243 & 0.0568 \\
Nitr & -0.385 & -0.798 & -0.164 & -0.152 & -0.1480 \\
SS & -0.225 & 0.873 & -0.079 & 0.199 & 0.0529 \\
pH & -0.186 & 0.252 & 0.735 & 0.304 & 0.0562 \\
IC & -0.088 & 0.287 & 0.031 & 0.910 & 0.0913 \\
Alka & 0.217 & 0.181 & 0.121 & 0.897 & 0.1323 \\
Sum of the components - $\mathbf{P}_{i}$ & 3.96 & 1.56 & 0.74 & 3.03 & 1.00 \\
Eigenvalues - F & 6.30 & 3.50 & 2.07 & 3.57 & \\
Unitary variance (\%) & 25.22 & 13.98 & 8.28 & 14.28 & \\
Accumulated variance (\%) & 25.22 & 39.20 & 47.48 & 61.77 & \\
\hline
\end{tabular}

${ }^{5}$ Chlor $=$ Chloride, Color $=$ Color, $\mathrm{EC}=$ Electrical Conductivity, $\mathrm{Mg}=$ Magnesium, $\mathrm{OC}=$ Organic $\quad$ Carbon, $\mathrm{Na}=$ Sodium, $\mathrm{Fe}=$ Iron, $\mathrm{Nitr}=$ Nitrate, $\mathrm{SS}=$ Suspended Solids, IC = Inorganic Carbon, Alka = Alkalinity. ${ }^{6}$ highligh values above or below 0.7

The variables for calculating the WQI proposed by this study, along with their respective weights, showing those which most influence the Water Quality Index, can be seen in Table 5.

A priori the largest weights in the variables related to the water salt concentration were obtained, highlighting them in order: EC, Color, Chlor, Mg, Alka and $\mathrm{Na}$. The EC was the variable which presented the largest weight, supporting the hypothesis that it is an indicator of salts in water, such as sodium and magnesium cations and chloride anions. That some ions may be associated with the change in electrical conductivity of the water, as observed in this study. The variable related to the nutrient load, denoted by nitrate, obtained negative weight, indicating that it was not possible to detect the increment of this type of agricultural fertilizer in the water during the monitoring.

Costelloe et al. (2005), monitoring the water salinity of the Neales-Peake, an ephemeral river in the arid Lake Eyre Basin, in Australia, observed spatial and temporal variability of the salts in the water, as in this study, attributed to the saline introduction done by the winds.

Andrade et al. (2005), proposing a WQI for the lower part of the basin of the river Trussu, in Ceará state, Brazil, found higher weights to the variables which compose salinity, that is, sodium, sodium adsorption ratio (SAR), CE and chloride. As in this study, the mentioned authors 
also found lower weights for nitrate and $\mathrm{pH}$, variables which indicate the presence of organic matter in the water course.

Toledo and Nicolella (2002), however, studying micro-watersheds under agricultural and urban soil use, found higher weights for the variables, which indicated the presence of organic pollution in the water, especially for the variables: nitrate, turbidity, ammonium, total solids and total phosphorus. This can be explained according to the authors for two main reasons: the effluents from a nearby town and the superficial runoff from agricultural areas that contribute to the increase in the load of phosphorus, ammonia and organic materials in the analyzed water.

The presence of the variables EC and color in the same factor is justified, because the color is conditioned in the water by the dissolved solids that can also favor the increase of the electrical conductivity of the water (CARVALHO et al., 2000). These dissolved solids can be derived from the salts present, degradation of the organic matter and other solids of the medium.

Also according to Table 5, it is noticeable that the variables related to the presence of organic compounds in water showed lower weights than others, such as OC, SS and pH, highlighting nitrate that, due to its high and negative weight, when inserted in the calculation will reduce the values of the WQI, contributing to the representation of indexes of the

improved water quality. The negative contribution of any variable was also observed by Toledo and Nicolella (2002), however the authors noticed the DO variable.

As for chloride, it presented the third biggest weight. Von Sperling (2005) explains that all natural waters, to a greater or lesser extent, contain ions from the dissolution of minerals. Chlorides $\left(\mathrm{Cl}^{-}\right)$arise from the dissolution of salts, for example, sodium chloride. He further explains that another factor responsible for the natural origin may be related to salinity intrusion in water - the action of the winds. This statement makes sense, because the micro-watersheds are within a distance from the sea that does not exceed $10 \mathrm{~km}$, especially the MW 2, that had its collection site at about $500 \mathrm{~m}$ from the sea and had the highest averages of this variable.

As for other characteristics, alkalinity, IC and $\mathrm{pH}$ are all basically related to the same constituents in the water, as mentioned in previous threads, as we can mention OC and the relationship between $\mathrm{Fe}$ and SS.

The index calculated for this case, thus, shall reflect greater sensitivity to salt concentration in water and lower sensitivity to the organic composition. This makes sense, since the collection sites of the micro-watersheds were located in areas of permanent preservation and distant from habitation and from creation of confined animals, thereby excluding possible human impacts by organic loads.

Another factor that confirms the previously related, is that nitrate, a major cause of remote pollution (VON SPERLING, 2005), presented a high negative weight, contributing to IQA values close to zero or even negative, which, in this method, indicates better water quality. The index used by Companhia Ambiental do Estado de São Paulo (2011), the lower the value of the result, the worse the quality of the water analyzed.

Andrade et al. (2005) explain that the indicator presented greater sensitivity to salt concentration because, according to the Principal Component Analysis, the wide variability of the data of the studied waters is explained by the first component, which is related to the salts present in the water.

NSF's (National Sanitation Foundation) WQI, one of the most used in the world to compare water quality, uses as the most relevant variables related to the loads of organic matter in water, such as DO, fecal coliforms, $\mathrm{pH}, \mathrm{BOD}$ (Biochemical Oxygen Demand), nitrate and total phosphorus, with the following weights: $0.17,0.15,0.12,0.10,0.10$, and 0.10 . Certainly, these variables will reflect mainly the human impacts on the water course, not taking into account other aspects as it was assessed in this study.

The WQI values calculated for each sample in each MW during the monitoring are shown in Figure 2. 
Figure 2 - Distribution of values of the Water Quality Index (WQI), on y axis to the left, in the sampling dates of the four studied micro-watersheds (MW's) (on the $\mathbf{x}$ axis) and the intensity of precipitation on the y axis to the right.

Figura 2 - Distribuição dos valores do Índice de Qualidade de Água (IQA), no eixo y à esquerda, nas datas de amostragens das quatro microbacias hidrográficas (MBs) estudadas (no eixo x) e a intensidade de precipitação no eixo y à direita.

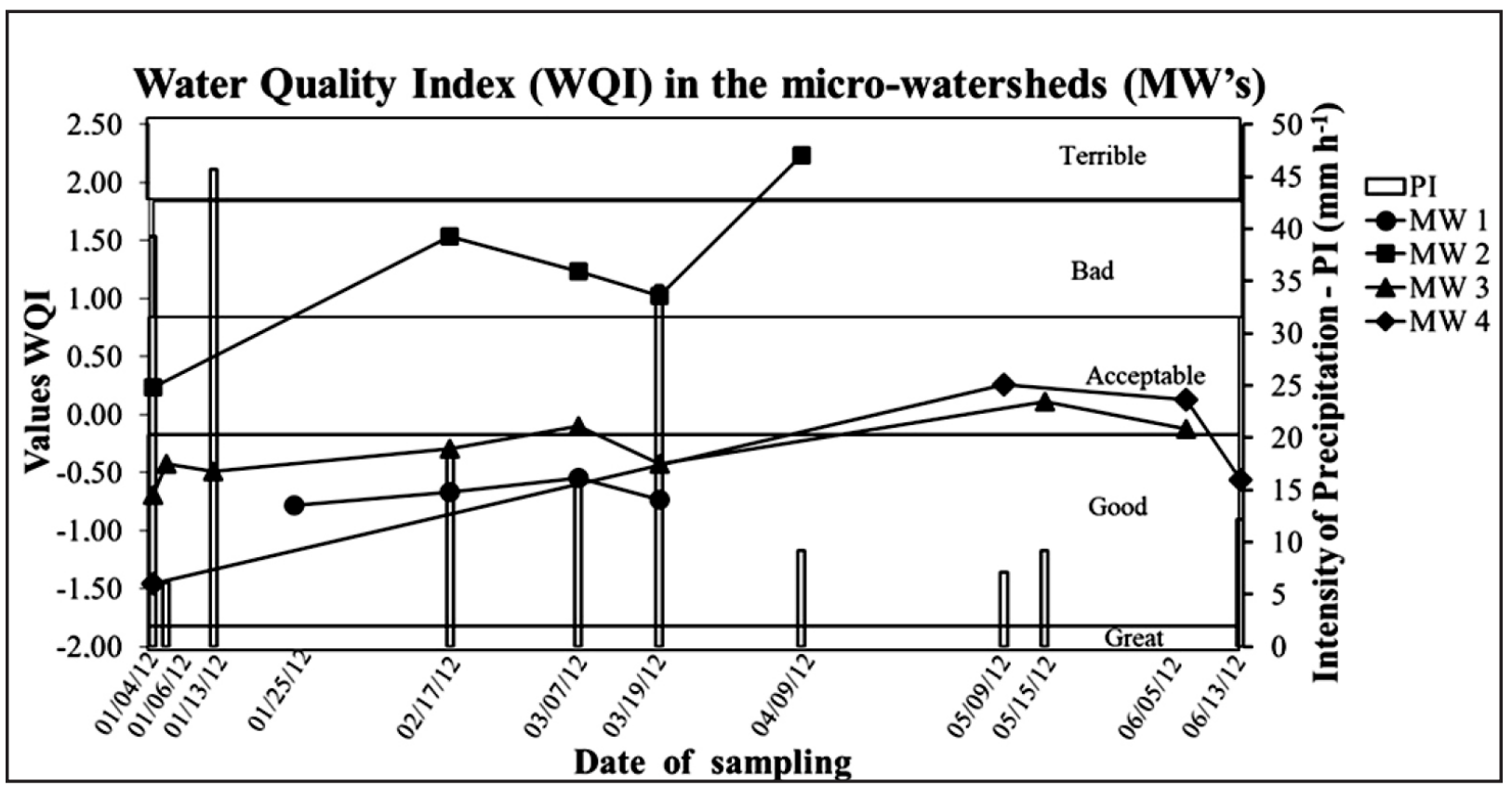

Source: Gardiman Junior et al. (2019)

Based on Figure 2, it is possible to observe a tendency to degradation of water quality and, consequently, an increase in the values of WQI of the micro-watersheds while the dry season approaches. Similar results were observed by Andrade et al. (2005) in the river Trussu, in Ceará state, recording the worst index in the dry season. According to the authors, the enrichment of salts and the decrease of nutrients in the water deteriorate its quality, changing the WQI.

Classifying the MW's for water quality, the index makes clear that the MW 2 shows a greater variation in water quality, leaving the "acceptable" class in the first collection, going through "bad" in the sequent collections, and last ranking as "terrible". This variation can also be proved by the higher standard deviation displayed in Figure 3, which gives MW 2 a lower water quality compared to the others. It was also noticeable using Figures 2 and 3 that the WQI values did not change much in MW 1, and remained throughout the monitoring in the "good" classification.

The MW 3, in the beginning of the first collections had indexes close to the ones of MW 1, having water considered as "good", except for the fifth collection that came close to the "acceptable" classification. However, at the end of the monitoring there was a deterioration in the water quality of this MW, which made it show higher rates, ending up at an "acceptable" classification.

The MW 4, at the beginning of monitoring, had a "good" classification in the first collection, but in the following two samplings, presented an "acceptable" quality, returning to "good" in the last collection. The evolution of the water quality of this MW may have been due to the rain event that preceded the collection. It is verifiable through Figure 3 that the MW 4 presented, as the MW 2, higher values of standard deviations when compared to the others, 
which confirms the high variation in water quality of this MW.

Figure 3 - Average values and standard deviations of the WQI in the sampling of the four monitored micro-watersheds monitored. Legend: micro-watersheds 1 (MW1), microwatersheds 2 (MW2), micro-watersheds 3 (MW3) and micro-watersheds 4 (MW4).

Figura 3 - Valores médios e desvios padrões do IQA nas amostragens das quatro microbacias monitoradas. Legenda: microbacia 1 (MW1), microbacia 2 (MW2), microbacia 3 (MW3) e microbacia 4 (MW4).

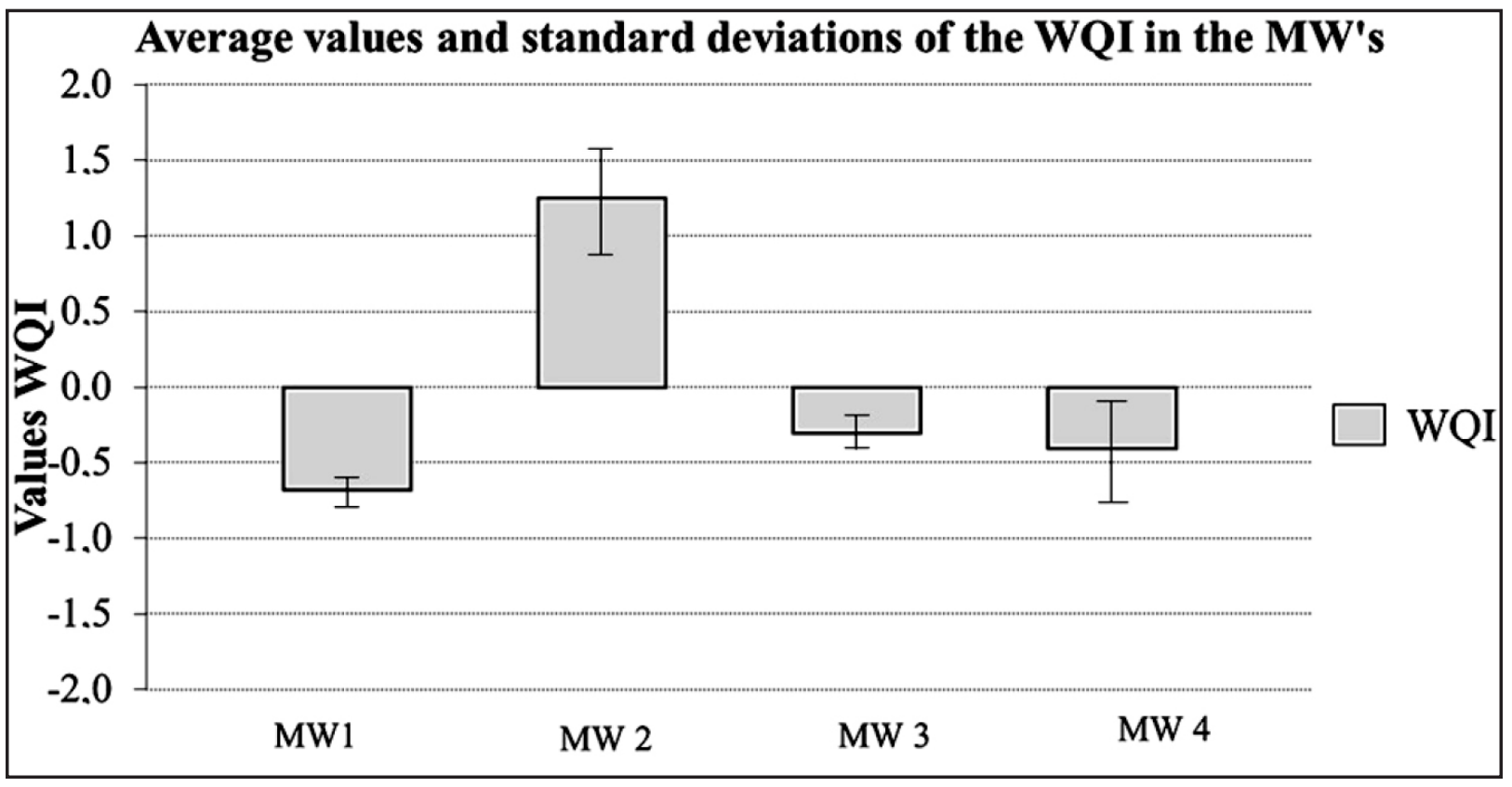

Source: Gardiman Junior et al. (2019)

Figure 3 presents a trend of the mean values of the WQI's in the MW's monitored. By means of that, it is possible to notice that MW 1,3 and 4, presented mean WQI values below zero, being $-0.68,-0.30$ and -0.41 , respectively, whereas MW 2 of 1.25 . As already, explained, lower values indicate better water qualities as larger values, worse. Regarding the deviations of the values of the calculated indices, it was observed that larger were recorded by MW $4(0.78)$, followed by MW 2 (0.72), MW 3 (0.25) and MW 1 (0.10), in that order. Larger deviations illustrate the sensitivity of the method in capturing water quality oscillations during monitoring.

Some factors may have been responsible for the time variation in the amount of water from the monitored micro-watersheds, leaving the constituents in the mass of water more concentrated and, consequently, varying the WQI. Among some, can be highlighted the small contribution area of the micro-watersheds, declivity, soil depth and water use of the tree species of APP's, due to the advanced stage of regeneration and weather conditions.

As for the weather, Andrade et al. (2005) showed temporal variations in the WQI values calculated and argue that the concentration of salts in the dry season and the dilution in the rainy season caused, consequently, a variation in the WQI values. Bordalo et al. (2001), when studying the water quality of the river Bangpakong in the east of Thailand, also showed similar values to those observed in this study. Unlike what was observed in this study, Almeida and Schwarzbold (2003), using NSF's WQI, noted the poor quality of the water when the river level was in higher, due to the influence exerted by variables such as turbidity, total solids in suspension and $\mathrm{pH}$. The results found by the authors is typical of watersheds that have little or no preservation area, 
especially those with watercourses, since the main function of preservation areas is to retain the solids provided by soil loss and transported to the watercourses through runoffs during heavy rains. Concerning to the size of the micro-watershed, Almeida and Schwarzbold (2003) monitored one with approximately 9600 hectares, that is, much larger than the ones monitored in this study. To Meybeck et al. (1996) apud Toledo and Nicolella (2002), the range of weather events and changes in water quality are directly related to the size of the micro-watersheds.

The variables related to the concentrations of salts in the water, in this study, were the most relevant, and it was proven that the quality of water decreases in times of lower rainfall intensity.

According to Lucas et al. (2010), in the dry season, there is a concentration of solute and minerals elements, such as sodium, due to the reduction of the flow. Meireles et al. (2007) point out that in some cases the concentrations of salts can even hinder the use of the water for human consumption and agriculture, especially in the dry season, when the decreasing of the runoff and the high temperatures in the region occur.

For this study, particularly, the weight of the nitrate favored the results of the calculated index. Srinivasan et al. (2003), believe that if the native vegetation had been severely degraded in times of high rates of rainfall, it would be possible to register an increase in nitrate concentrations, a likely consequence of the entrainment of material from the surface layers of the soil. However, what was illustrated by these authors was not observed in the areas monitored by this study.

Similarly, Carvalho et al. (2000) also found a seasonal variation in the water quality of the streams "Feijão" and "Onça", in São Paulo, registering improvement during winter. The authors attribute these seasonal variations to precipitation, which, in addition to dilute the concentration of waste, increase the superficial runoff of the soil, showing a reduction of the water quality through a WQI.

Toledo and Nicolella (2002), using the same method employed in this work, justified that, since the WQI is as a statistical variable, with predominant contribution of the primary variables, variations in it are strongly associated with changes in water quality, unlike the separated study of each variable.

The numerical analysis of the WQI values allowed the elaboration of an index to supplant the evaluation of surface waters, resulting from a monitoring both spatial and temporal of the average variables of quality of the waters collected in micro-watersheds. Based on that evaluation, it was possible to determine the watersheds, as well as the time of the year, with worse and better water quality.

\section{Conclusions}

Based on the analysis conducted in the studied area, it was possible to conclude that the water from the monitored micro-watersheds decreased in quality as the frequency of rainfall also decreased.

Among the variables analyzed, the most sensitive to the variation of the silvicultural activities developed, affecting the water quality of the hydrographic basins, were: $\mathrm{Mg}, \mathrm{Na}$, Organic Carbon, Chloride, EC, Color, Fe, Nitrate, Suspended Solids, pH, Inorganic Carbon and Alkalinity.

The proposed Water Quality Index (WQI) was efficient to compare the quality of the waters of the monitored micro-watersheds, and it can be used to classify waters, instead of studying individually each variable.

The highest WQI value was registered in the MW 2, related to the highest load of salt in the water, due to the proximity of the sea. The lowest WQI was registered in MW 1, associated with the smallest change in water quality.

It was not possible to detect a relationship between the silvicultural activities developed within the MW's and the change on one or more water quality variables that make up the WQI. 
Preservation areas conserved with native species along the banks of the watercourses may have minimized the impacts generated by the activities developed, retaining nutrients, reducing surface runoff, favoring infiltration, balancing the flow of the river water, etc.

\section{Acknowledgements}

To the Espírito Santo Federal Institute (IFES) for the financial support dedicated to the translation of this article.

\section{References}

ALMEIDA, M. A. B.; SCHWARZBOLD, A. Avaliação sazonal da qualidade das águas do Arroio da Cria Montenegro, RS com aplicação de um Índice de Qualidade de Água (IQA). Revista Brasileira de Recursos Hídricos, Porto Alegre, v. 8, n. 1, p. 81-97, jan./mar. 2003.

ALVARES, C. A. et al. Köppen's climate classification map for Brazil. Meteorologische Zeitschrift, Stuttgart, v. 22, n. 6, p. 711-728, 2013.

ANDRADE, E. M. de et al. Fatores determinantes da qualidade das águas superficiais na bacia do Alto Acaraú, Ceará, Brasil. Ciência Rural, Santa Maria, v. 37, n. 6, nov./dez. 2007a.

ANDRADE, E. M. de et al. Índice de qualidade de água, uma proposta para o vale do rio Trussu, Ceará. Revista de Ciência Agronômica, Fortaleza, v. 36, n. 2, p. 135-142, maio/ago. 2005.

ANDRADE, E. M. de et al. Investigação da Estrutura Multivariada da Evapotranspiração na Região Centro Sul do Ceará pela Análise de Componentes Principais. Revista Brasileira de Recursos Hídricos. Porto Alegre, v. 8, n. 1, p. 39-44, jan./mar. 2003.

ANDRADE, E. M. de et al. Seleção dos indicadores da qualidade das águas superficiais pelo emprego da análise multivariada. Revista Engenharia Agrícola, Jaboticabal, v. 27, n. 3, p. 683690 , set./dez. 2007 b.

AMERICAN PUBLIC HEALTH ASSOCIATION. Standard Methods for the Examination of Water and Wastewater. 20 $0^{\text {th }}$ [S. l.]: APHA, 2005.

ASSOCIAÇÃO BRASILEIRA DE NORMAS TÉCNICAS. NBR 9898: Preservação e técnicas de amostragem de efluentes líquidos e corpos receptores. Rio de Janeiro, 1987. 22 p.

BARROS, R. V. G. et al. Determinação do Índice de Qualidade da Água (IQA) na sub-bacia do córrego André em Mirassol d'Oeste, Mato Grosso. Engenharia Ambiental, Espírito Santo do Pinhal, v. 8, n. 3, p. 138-153, jul./set. 2011.

BORDALO, A. A. et al. Water quality and uses of the Bangpakong river (eastern Thailand). Water Research, Amsterdam, v. 35, n. 15, p. 3635- 3642, 2001.

BONNET, B. R. P. et al. Relações entre qualidade da água e uso do solo em Goiás: uma análise à escala da Bacia Hidrográfica. Revista Árvore, Viçosa, MG, v. 32, n. 2, p. 311-322, 2008.

CARVAlHO, A. P. et al. Determinação espacial e temporal do IQA do açude Soledade em Soledade-Paraíba. Engenharia Ambiental, Espírito Santo do Pinhal, v. 8, n. 2, p. 138-147, abr./ jun. 2011.

CARVALHO, A. P. et al. Relação da atividade agropecuária com parâmetros físico-químicos da água. Química Nova, São Paulo, v. 23, n. 5, 2000.

COMPANHIA AMBIENTAL DO ESTADO DE SÃO PAULO. Apresenta o índice de qualidade de águas - IQA. São Paulo: CETESB, 2011. Disponível em: http://www.cetesb.sp.gov.br/ agua/\%C3\%81 guas-Superficiais/42-\%C3\%8Dndice-de-Qualidade-das-\%C3\%81guas-(iqa). Acesso: 31 ago. 2011. 
COSTELLOE, J. F. et al. Spatial and temporal variability of water salinity in an ephemeral, aridzone river, central Austrália. Hydrology Process, Reino Unido, n. 19, p. 3147-3166, 2005.

GERGEL, S. E. et al. Landscape indicators of human impacts to riverine systems. Aquatic Science, Canadian, v. 64, p. 118-128, 2002.

GIRÃO, E. G. et al. Seleção dos indicadores da qualidade de água no Rio Jaibaras pelo emprego da análise da componente principal. Revista Ciência Agronômica, Fortaleza, v. 38, n. 1, p. 17-24, 2007.

GRÜTZMACHER, D. D. et al. Monitoramento de agrotóxicos em dois mananciais hídricos no sul do Brasil. Revista Brasileira de Engenharia Agrícola e Ambiental, Campina Grande, v. 12, n. 6, p. 632-637, 2008.

GUIMARÃES, R. Z. et al. Avaliação dos impactos da atividade de silvicultura sobre a qualidade dos recursos hídricos superficiais. Scientia Forestalis, Piracicaba, v. 38, n. 87, p. 377-390, set. 2010.

HAASE, J. POSSOLLI, S. Estudo da utilização da técnica de Análise Fatorial na elaboração de um índice de qualidade de água: comparação entre dois regimes hidrológicos diferentes. Acta Limmologica Brasillensia, Rio Claro, v. 6, n. 1, p. 245-255, 1993.

LOPES, F. B. et al. Proposta de um índice de sustentabilidade do Perímetro Irrigado Baixo Acaraú, Ceará, Brasil. Revista Ciência Agronômica, Fortaleza, v. 40, n. 2, p. 185-193, abr./jun. 2009.

LUCAS, A. T. et al. Qualidade da água em uma microbacia hidrográfica do Rio Piracicaba, SP. Revista Brasileira de Engenharia Agrícola e Ambiental, Campina Grande, v. 14, n. 9, p. 937943, 2010.

MEIRELES, A. C. M. et al. Sazonalidade da qualidade das águas do açude Edson Queiroz, Bacia do Acaraú, no Semiárido cearense. Revista Ciência Agronômica, Fortaleza, v. 38, p. 25-31, 2007.

MENEZES, M. D. et al. Dinâmica hidrológica de duas nascentes, associada ao uso do solo, características pedológicas e atributos físicos-hídricos na sub-bacia hidrográfica do Ribeirão Lavrinha-Serra da Mantiqueira (MG). Scientia Forestalis, Piracicaba, v. 37, n. 82, p. 175-184, 2009.

MOURA, L. H. A. et al. A qualidade de água como indicador de uso e ocupação do solo: bacia do Gama - Distrito Federal. Química Nova, São Paulo, v. 33, n. 1, p. 97-103, 2010.

NUNES, D. G. et al. Índice de Qualidade da Água em trechos do rio Turvo Sujo, Viçosa - MG. Engenharia na Agricultura, Viçosa, MG, v. 19, n. 5, p. 459-468, set./out. 2011.

SILVA, G. S. da et al. Um novo índice de qualidade das águas para proteção da vida aquática aplicado ao rio Atibáia, região de Campinas/Paulínia - SP. Química Nova, São Paulo, v. 29, n. 4, p. 689-694, 2006.

SRINIVASAN, V. S. et al. Erosão hídrica do solo no semi-árido brasileiro: a experiência na bacia experimental de Sumé. Revista Brasileira de Recursos Hídricos, Porto Alegre, v. 8, n. 2, p. 57-73, abr./jun. 2003.

TOLEDO, L. G.; NICOLELLA, G. Índice de qualidade de água em microbacia sob uso agrícola e urbano. Scientia Agrícola, São Paulo, v. 59, n. 1, p. 181-186, jan./mar. 2002.

VON SPERLING, M. Princípios do tratamento biológico de águas residuárias: Introdução à qualidade das águas e ao tratamento de esgotos. 3. ed. Belo Horizonte: UFMG, 2005. v. 1, 452 p. 